Marquette University

e-Publications@Marquette

Social and Cultural Sciences Faculty Research and

Publications

Social and Cultural Sciences, Department of

$1-1-2003$

Black Single Custodial Fathers: Factors Influencing the Decision to Parent

Roberta Coles

Marquette University, roberta.coles@marquette.edu

Published version. Families in Society, Vol. 84, No. 2 (2003): 247-258. DOI. (C) 2003 Alliance for Children and Families. Reprinted with permission from Families in Society (www.FamiliesInSociety.org), published by the Alliance for Children and Families. 


\title{
Black Single Custodial Fathers: Factors Influencing the Decision to Parent
}

\author{
Roberta L. Coles
}

\begin{abstract}
This pilot study combined narrative and quantitative data to explore the factors enabling and motivating single African American fathers to take full custody of one or more of their children. The size and selection of the sample does not allow for generalization, since most of the men were college-educated and financially stable. The findings indicated a distinction between enabling and motivating factors. Factors that appeared to enable full custody included employment and secure housing, as they were present for all of the fathers before they took custody. Adult age at the time of their first child's birth was also a factor for 9 of the 10 fathers. Prior parental involvement, previous marital status, and maternal incompetence did not appear to be highly associated with the choice to take custody. However, the narrative data indicated that the desire to embody the kind of father they themselves did not have was a strong motivating factor.
\end{abstract}

WHETHER IT'S IN THE POPULAR MEDIA or academic literature, Black men are not frequently viewed within a family context. A number of researchers ${ }^{1}$ have begun to study married or cohabiting fathers with respect to their child-rearing values, provider role, or gender relations. However, most recent studies ${ }^{2}$ and the burgeoning number of social programs on "responsible fatherhood" (Johnson \& Sum, 1987; Pirog-Good, 1993; Savage, 1987) have concentrated on nonresident single Black fathers, viewing them primarily as a social problem and as the prototype of the Black man. Policymakers' narrow definition of family values and academia's narrow focus on the high rates of divorce, cohabitation, and teen and nonmarital births among African Americans have led to a close association between the concepts of Black father and "absent father."3

Fortunately, some of these researchers (Danziger \& Radin, 1990; Seltzer, 1991; Taylor Chatters, Tucker, \& Lewis, 1990; Wattenberg, 1993) have found that the lack of marriage or coresidence with the mother is not necguessarily predictive of parental noninvolvement, as might be inferred from the term absent. In particular, a larger than suspected proportion of nonresident Black fathers often maintain relatively high levels of informal involvement, such as visiting, diapering, and taking children out to play. In fact, fatherhood is turning out to be a varied and complex arrangement that defies simplistic categories.

Despite these improvements in broadening the research territory, no researchers have looked at single African American men who parent full-time, despite the fact that most data indicate Black single-father households have been increasing over the past 2 to 3 decades. Single fatherhood appears to be increasing among all races, though there is some disagreement as to the exact rates. According to a New York Times report, the number of father-only families was 2.1 million in 1998, up from 1.7 million in 1995 ("Single Fathers," 1998). According to Greif (1990), during the

l See, for instance, Ahmeduzzaman and Roopnarine (1992); Allen (1981); Bowman (1993); Bright and Williams (1996); Fagan (1998); McAdoo (1981, 1988a, 1988b, 1993); McAdoo and McAdoo (1994); Mirande (1991); Taylor, Leashore, and Toliver (1988); and Wade (1994).

2 Such as Barnes (1987); Christmon (1990a, 1990b); Furstenberg, Morgan, and Allison (1987); Furstenberg and Harris (1993); Hawkins and Eggebeen (1991); Lerman (1993); Lerman and Ooms (1993); Marsiglio (1987, 1991a); Miller (1994); Mott (1990); Rivara, Sweeney, and Henderson (1986); and Robinson (1988).

3 The rate of teen pregnancy has been declining among African Americans in the last few years, and one of the main contributing factors in the apparent rise in the proportion of nonmarital births among African Americans is the declining rate of marriage and fertility rates among married Black women.

Families in Society: The Journal of Contemporary Human Services

Copyright 2003 Alliance for Children and Families 
1980 to 1987 period single-father custody grew by $50 \%$, whereas single-mother custody rose by $16 \%$.

The specific numbers of Black father-headed families are foggy as well. Eggebeen, Snyder, and Manning's 1996 study using National Survey of Families and Households data, indicated that single-father families represented $15.5 \%$ of all single-parent families with children and that single-father families were increasingly being formed by fathers who are young, have never been married, have low incomes, and have fewer children. In each decade from 1960 to 1990, they found non-White children more likely than White children to reside in father-only families. Eggebeen et al.'s reading of census data indicated that by $1990,3.3 \%$ of White children were in father-only families, compared with $5.6 \%$ of Black children. However, 1992 U.S. Census Bureau data ("Diverse Living Arrangements," 1993) showed a narrower gap-3.4\% of Black children 17 years old or younger lived in father-only households compared with $3.3 \%$ of White children.

The confusion of these numbers is frequently exacerbated by the use of various terms-single-father, unwed father, father-only, lone fathers, father-custody, and male-headed families-without distinguishing among them. For instance, father-custody families can include fathers who have remarried (Dowd, 1997, estimated that $41 \%$ of fathercustody families are remarried men), and because Black men have lower rates of marriage and remarriage than White men, the percentage of White father-custody households would be larger relative to Black father-custody households, even though the percentage of White single father households might be lower (Zill, 1988).

In any case, the proportion of African American singlefather families seems to be at least as high as or higher than that of White single-father families. Nonetheless, the glut of studies focusing on single-father families has focused on White fathers. ${ }^{4}$ Not one has focused on African American single fathers who have custody of their children.

Despite the fact that African American men tend to be disadvantaged in terms of education, employment, income, and health in comparison to White men (Davis 1999), it appears that they are as likely or more likely to take on the task of single parenting. Hence, it is important to begin to determine (a) what factors enable and motivate such men to choose to be single custodial fathers, (b) how they parent and the effects on their children, and (c) what benefits and disadvantages attend to the fathers themselves. In this article I address the first of these questions and discuss the implications these findings might have for social service agencies.

\section{Brief Review of the Literature on Single Fathers}

To date, research on single fathers, as stated earlier, has focused primarily on White men. While direct comparison between Black and White fathers is not the intent here, the lack of literature on Black single fathers leaves the literature on White single fathers as the only feasible option for a theoretical context. Those researching White single fathers have looked at a number of factors that seem to play a role in each individual father's decision. Some of those factors include income and employment, previous marital status, parental involvement prior to separation from the mother of the child, access to a support system, and gender of the child.

In the choice to parent, the availability of resources is often a major consideration. Past studies of single men have indicated that single, full-time fathers tend to have a higher income and more full-time employment and are less likely to rely on various forms of social welfare than single mothers (Chang \& Deinard, 1982; Dowd, 1997; Downey, 1994; Gersick, 1979; Greif, 1985, 1990; Guttman, 1982; Hanson, 1985a, 1986a, 1988; Meyer \& Garasky, 1993; Orthner et al., 1976; Risman, 1986; Santrock \& Warshak, 1979). For instance, Greif and DeMaris (1995) surveyed 117 single White dads, and they found that the average income was $\$ 7,000$ more than the average income for single White men as a group. Meyer and Garasky's 1993 study of Current Population Survey data found custodial dads had an income $187 \%$ greater than that of custodial moms. However, none of the studies controlled for income in relation to length of custody. Although one might safely assume that greater financial resources at the time of custody contributed to the court and/or mother deciding that father custody might be better, one can't be certain that custody didn't help their income improve.

It has been suggested that single fathers, because of their rarity, receive more sympathy and hence more help from family and friends. For instance, Santrock and Warshak's 1979 study of 60 families (one third single dads, one third single moms, and one third married couples) revealed that single fathers relied on family assistance for twice as many hours per week as did single mothers. However, most researchers (Barker, 1994; Gladding \& Huber, 1984; Hanson, 1988) have reported that single fathers are less likely than single mothers to rely on services from family, friends, or hired help. For instance, O'Brien's 1987 study showed that only $20 \%$ of lone fathers saw their siblings weekly, and $42 \%$ saw their parents less than once or twice a year, although family contact was higher among workingclass single dads. Mendes (1976b) and Bartz and Witcher (1978) found that while some single fathers had initially hired someone to do housekeeping, eventually they and the children did the vast majority of the housework.

A number of researchers have tried to discern whether single custodial fathers are more likely to have been men who were more involved as parents prior to the divorce or separation. The results have been mixed. Gersick (1979)

\footnotetext{
4 See Barker (1994); Bartz and Witcher (1978); Chang and Deinard (1982); DeFrain and Eirick (1981); Gasser and Taylor (1976); George and Wilding (1972); Gersick (1979); Greif (1982, 1985, 1990); Greif and DeMaris (1989); Hanson (1981, 1986a, 1986b); Hipgrave (1982); Katz (1979); Keshet and Rosenthal (1978); McKee and O'Brien (1983); Mendes (1976a, 1976b); Orthner, Brown, and Ferguson (1976); Robinson and Barrett (1986); Risman (1986); Rosenthal and Keshet (1981); Santrock and Warshak (1979); Smith and Smith (1981); and Tedder, Libbee, and Scherman (1981).
} 
and Grief (1990) found that single dads were not more likely to have been more involved than other fathers, but most studies have indicated a positive correlation between prior involvement and custody (Bartz \& Witcher, 1978; Greene, 1977; Hanson, 1981, 1986b; Risman, 1986; Smith \& Smith, 1981; Turner, 1984).

Several researchers (Furstenberg, 1995; Furstenberg \& Harris, 1993; Selzter, 1991) have found that marital status at the time of the birth of a child helps to determine the degree of involvement of the father upon separation. Nonresident fathers tend to be more involved over the long term if they were previously married to the mother (Furstenberg \& Harris, 1993; Lerman, 1993). Likewise, studies of single fathers, which are again largely based on White men, have found the majority of them to have been divorced rather than never married.

Although, findings are mixed, researchers tend to find that the custodial child's gender plays a role in father custody; fathers are more likely to take custody of boys. For instance, Grief's 1990 study of more than 900 single fathers $(96 \%$ White) found that $42 \%$ of the fathers had boys only, $27 \%$ had girls only, and $31 \%$ had both. Chang and Deinard (1982) found that $57 \%$ of the households in their study had boys and $43 \%$ had girls. Meyer and Garasky (1993) found that $56 \%$ of custodial children in single-father households were boys. A number of researchers (Ihinger-Tallman, Pasley, \& Buehler, 1995; Marsiglio, 1991b; Morgan, Lye, \& Condran, 1988) concluded that the sex of the child may predict involvement on the part of the father because of shared interests (meaning fathers share more interests with boys than with girls) and because mothers may press for more father involvement when the child is a son.

The father's own family background has been another factor considered in the research on father custody. Grief's 1990 study of custodial fathers revealed that $80 \%$ of them had been raised in two-parent families for most, if not all, of their childhood. Nevertheless, a number of studies (Gersick 1979; Mendes, 1976a, 1976b) of custodial fathers have indicated that the fathers identified more or had more intense relationships with their mothers and more emotionally distant relations with their fathers. Gersick (1979) attributed this to the fact that their mothers were more likely to have been homemakers. Hanson (1981, 1985a) found that although single custodial dads reported their fathers to be their primary parental model, they nevertheless reported being emotionally closer to their children than their fathers had been to them.

For this study, in which I use both quantitative and qualitative methods, I assess the importance of the above factors but also address motivational considerations that might be overlooked in purely quantitative studies. Although the quantitative data support the importance of employment and availability of a support network, qualitative data indicate that fathers were highly motivated by the desire to pre- vent an intergenerational pattern of absent fathers and that they wanted to be a role model for their offspring.

\section{Methodology}

\section{Study Design and Measurements}

This convenience sample of 10 African American fathers was recruited mostly in Milwaukee and Madison, Wisconsin, through schools, neighborhood centers, adoption agencies, parenting resource centers, fatherhood projects, churches and Islamic centers, related Web sites, the fathers themselves (snowball sampling), and advertising in local alternative newspapers and radio stations. They were the first 10 respondents in an ongoing ethnographic study of African American, single, full-time fathers. My intent in obtaining and analyzing this initial sample was to evaluate the feasibility of a larger study, to test the venues for locating respondents, and to begin to build theory and research questions for future research in this new, full-time fatherhood territory. Although potential interviewees are still being contacted, further interviews are on hold pending further funding.

Fathers were admitted to the study on the basis of their racial identity and custodial status. "Racial identity" was self-identified. One father was biracial, but he identified more with African American heritage. Custodial was defined as the child residing with the father at least 5 days per week. Custody may be formal, that is, legalized through the court, or informal, that is, arranged by the parents or family without the courts' intervention. Custody may also follow a nonmarital birth, divorce, adoption, or widowhood. In this case, 3 of the fathers were divorced from the mother of the custodial child. Six of them had never married the mother, though most of the nonmarital group had cohabited with the mother for some period of time. ${ }^{5}$ One had custody through adoption. None was a widower. Five of the fathers had legal custody, that is, custody adjudicated by the courts. The other 5 had made informal arrangements with the mother through mutual agreement that father custody would be best in their individual situations.

Fathers first filled out a 10-page quantitative questionnaire that elicited demographic information about them and their children and addressed their family background, parenting style and philosophy, existence and proximity of support system, distribution of household labor and childcare, and a limited number of measurable outcomes for child and father. Upon completion of the questionnaire, fathers participated in a 2-to 3-hr in-depth interview with the primary researcher or an assistant. Two of the interviews were conducted via email, but all of the other interviews were conducted at a mutually agreed upon location, most often the home of the father. The interview included questions designed to explore the motivation and factors considered in the decision to parent full-time, definitions of and priority given to various parenting roles, and satisfaction with choices made and

\footnotetext{
5 This is just slightly different from U.S. Census figures (Cochran, 1997) that estimate that $23 \%$ of Black custodial fathers are divorced and $54 \%$ are never married.
} 
outcomes. Interviews of these 10 men occurred from the end of 1999 through 2000.

To try to determine the factors influencing the custody decision, I designed the questionnaire to include quantitative measures of employment and income, social support, family background, level of prior involvement, and prior marital status, which were anticipated to play a role in choosing custody. The qualitative in-person interview included open-ended questions designed to elicit other factors, definitions of and priority given to various factors, and the motivations that may have played a role in each father's decision.

Regarding economic and educational resources, I designed quantitative questions that were frequently framed in two time periods - current status and status at the time of custody. The purpose of seeking data for both current status and at the time of custody was two-fold. Obviously, fathers made their initial decisions within the economic conditions present at the time they took custody, not on the basis of their current economic status. For the few who had taken custody fairly recently, the indicators were essentially unchanged. But because most of the fathers had had custody for at least 2 years, it was important to try to ascertain the data for the initial custody period as accurately as possible within the limitations of oral data collection. Also, for purposes not addressed in this article, I wanted to be able to determine the effect custody had on the father's economic situation, and so a comparison of the two time periods was needed as well.

The questionnaire asked whether fathers were employed at time of custody and/or currently, whether employment was full- or part-time, whether they held more than one job, and what type of occupations they held. They also were required to estimate their yearly income at the time of custody and currently. The ranges were "less than \$15,000,” “\$15,000-\$24,999,” “\$25,000-\$34,999," “\$35,000-\$49,999," and “more than \$50,000." They were asked to list all sources of income, including jobs, public aid (such as Temporary Assistance for Needy Families [TANF], food stamps, Medicaid, and rent and/or child care subsidies), regular help from family or friends, investment income, and income from the mother of the child. Therefore, fathers were also asked to give their level of education currently and at the time of custody. The options were "less than a high school diploma," "high school diploma," "some college," "college graduate," and "more than a college education."

Housing was also considered a resource, and for this fathers were asked whether they owned or rented an apartment or single-family house now and at the time they took custody. They were also asked how long they had lived at the current residence and how many times they had moved since taking custody, and they were asked to describe the current neighborhood in terms of class (poor, working class, middle class, or mixture of [name the classes]) and race ("mostly the same race as you," "mixed [name the races]," or "mostly of another race [name the race])."

Lastly, in terms of social support resources, fathers were requested to list whether anyone other than the father and child lived in their household. This question helped to determine whether extended family or "significant others" might be playing a daily role in caretaking. They were also asked to list family members who lived within 5 to 10 miles of their residence. For each person named above, fathers estimated the frequency of contact (daily, weekly, monthly, or less often) and the nature of contact (social or assistance). If any of the named persons were designated as being of assistance, the questionnaire broke the type of assistance down further into laundry, cooking, dishes, house cleaning, outside chores, repairs, child care, and advice. For each type of assistance, fathers were required to estimate in hours per week the amount of assistance given by each person. The categories of "friends" and the "child's mother" were automatically added to the list of named persons, so that the nature of contact with these people could also be discerned. In addition, fathers were asked whether and how frequently they dated and whether they were in a serious relationship.

To measure the father's level of prior involvement in child care and household duties, the questioner asked fathers to estimate the amount of time they spend in the chores mentioned above currently and then to compare that to the amount of time spent doing those chores when they coresided with the mother and child. If there had been a period of nonresidence with the child, fathers were asked in the qualitative interview to describe the frequency and type of contact they had had with the child.

Marital status was obtained by a quantitative question asking what had been the father's marital status (divorced, married, never married, cohabiting, widowed) at the time of birth of each custodial child. All fathers were required to be currently single in order to be part of the study. They could have been currently cohabiting, but none was.

Fathers listed the age, sex, and first name of each custodial child. For each child, fathers also gave the length of custody, the mother's first name (in case each custodial child had a different mother), and designated whether the child was biologically related. Fathers were asked to supply the same information for any nonresident biological children. In the qualitative interview, fathers were asked whether they took any responsibility (financial or otherwise) for any nonbiologically related children and, if so, why.

For each birth mother, fathers were asked to give her first name, her age at the birth of the child, and her educational level. In the interview, fathers were asked if they or the court considered the mother to be incompetent and why. In addition, fathers were asked to designate whether they took custody through formal (court-ordered) or informal (by 
agreement with the mother) means. Qualitative questions elicited more details about the custodial process.

For the fathers' own family background, fathers were asked whether they spent most of their childhood in a two-parent household, single-parent household, or a combination of both. If they said both, they were asked how long it was a single-parent household: "less than five years," "6-10 years," or "more than 11 years." In all cases, fathers were asked which parents were employed, which parent was the primary caregiver, which parent they felt closest to, and which was a role model for their own parenting. Fathers had the option of answering "equally both" or "equally neither" in addition to "mother" or "father." Specifically, fathers were asked whether they considered their own fathers to be "nurturing."

Qualitative questions built on the answers to the quantitative questions each father gave, asking them to define what they meant by "role model," for instance, or to explain why they gave the answer they did. Also, the qualitative interview included more general questions, such as "What factors did you consider in your decision to take custody?" or "What were some of the pros and cons you thought about in making the decision?" or "What motivated you to take custody of your child?"

I used both quantitative and qualitative methods because I assumed that some factors, such as higher income and full employment or older age of father at birth of child, might consistently be present but not have played a salient motivating role for the father himself. Likewise, the motivating forces apparent in the fathers' discursive accounts might not be anticipated in the quantitative questionnaire.

\section{Sample Profile}

Although the sample is neither random nor large enough to generalize from, recruiting from the wide variety of sources produced a fairly diverse group of respondents in terms of age, education, income, and employment. Eight of these 10 fathers resided in Wisconsin (either from Milwaukee or Madison), l was from New Jersey, and 1 was from Michigan (the latter two were contacted through one of several Web sites related to single fathers). Their ages ranged from 20 to 43 years old at the time of the interview. Two of the fathers were in their 20s, 4 were in their 30s, and another 4 were in their $40 \mathrm{~s}$. Nine of the men were at least majority age when their child was born, 5 were in their 20 s, and 2 were in their 30 s at the time of their first child's birth. Two fathers had a high school diploma, 2 had some college, 5 had a college degree, and 1 had a master's degree. Two of the men had incomes between $\$ 15,000$ and $\$ 24,999,5$ had incomes between $\$ 25,000$ and $\$ 34,999$, 1 had an income between $\$ 35,000$ and $\$ 49,999$, and 1 had an income over $\$ 50,000$. All of them were employed full-time; occupations included factory worker, plumber, state administrator, corporate manager, Air Force officer, elementary school teacher, and social worker. Five of the fathers held additional part-time employment as sport coaches, building manager, taxi driver, or disc jockey.

The custodial children were also diverse in regard to age, gender, and length of custody. There were 13 custodial children altogether. Most of the fathers (7) had custody of all of their biological children, but 3 had other biological children of whom they did not have custody. Seven fathers had one custodial child, and 3 had two custodial children. The custodial children's ages ranged from 1 year to 16 years. Three $(23 \%)$ of the children were under 5 years old, $7(54 \%)$ were young school-aged (6-12 years old) children, and $3(23 \%)$ were teenagers. A slight majority (7 of the 13) of custodial children were female. Length of custody as a single father at the time of the interview ranged from 5 months to 12 years. Three of the fathers had had custody less than a year. Four had had custody for 2-4 years, and 3 had had custody for at least 7 years.

\section{Findings and Discussion}

Given the size of this sample, the following analysis should be considered exploratory and the findings provisional. Nevertheless, as stated earlier, the intent of this study was not to test theory but rather to build theory from the ground up for future research in this new territory of fatherhood and to give voice to a previously unresearched group of fathers. In a number of ways this group of single fathers is similar to the profile of single fathers developing in the growing body of research on this topic, but there were a number of prominent characteristics and ways of talking about their decision to parent that distinguished these men from the general profile and raised some issues for further research.

\section{Employment and Other Resources}

As mentioned earlier, all of the fathers in this small sample were employed full-time at the time of the interview, and about half were employed more than full-time. All but 2 were employed full-time when they took custody; the 2 exceptions had been employed part-time and then moved to full-time at the time of custody. Hence, for all of them the vast majority of their income stemmed from their salaries. Because incomes were given in $\$ 10,000$ ranges, an exact average income could not be calculated, but most of the current incomes fell within the $\$ 25,000$ to $\$ 50,000$ range. The median income for Black men for the 1999-2000 period was between $\$ 20,579$ and $\$ 21,662$ (U.S. Census Bureau, 2002), so this sample's current income was higher, as would have been expected. Income at the time of custody was in a lower range (one to three range levels lower) for half of the men.

To the extent that nonsalaried income existed, it came from a variety of sources. Only 1 father was receiving (or had ever received) welfare monies in the form of food 
stamps and subsidized housing and childcare, and the adoptive father was receiving a monthly stipend for special-needs adoptions. Only 1 father was receiving child support payments from the mother. In fact, 1 was still paying child support to the now noncustodial mother because his custody of their daughter was arranged informally, and he feared that if he stopped payment, the court would intervene and take his daughter away. Several of the never-married fathers had paid child support either formally through the system or informally directly to the mother. Moreover, those fathers were still having their wages and annual tax refunds garnished to repay the state for the mothers' past receipt of Aid to Families with Dependent Children (AFDC). This lack of income subsidy is congruent with Brown's (2000) study of single fathers, in which he found that no more than $7 \%$ of the fathers in his study received child support, and no more than $15 \%$ of fathers received public assistance.

The prevalence of full employment and average or better income relative to single Black men is consistent with other research on single fathers, which has concluded that full-time single fathering in America tends to occur more often among men who are financially stable and better off compared to both their male and female counterparts. Several researchers (Danziger \& Radin, 1990; Furstenberg, 1995) have argued that lack of employment produces decreased father involvement in the form of less marriage, visitation, and cohabitation. However, several other researchers (Lerman, 1993; American Economic Review 1989) found that in the aggregate, increased employment rates led neither to an increased marriage rate nor to a lower nonmarital birth rate among Black men. The findings here add to that conundrum by suggesting that in the cases where men do become unmarried fathers $(70 \%$ of this sample), employment may make them more likely to take on full-time parenting. However, the reverse possibility, that custody makes long-term employment more likely, should also be explored.

Given the findings of past research on single fathers, one would have predicted that employment and income would have played a major role in the decision to take custody, yet in the qualitative interviews only a few fathers mentioned employment as a conscious consideration in their custody decision. Several fathers felt that if necessary, they would have taken custody anyway, even if they had not been employed.

In addition to employment, a stable residence also appeared to play a strong role in the custody decision. The 3 divorced fathers, all of whom had immediate sole custody, retained the house or apartment they had lived in. If they did not already have their own residence, most of the never-married fathers waited until they did to take custody. One father was living with some friends when he took custody of his son, but he waited until he obtained his grandmother's home to take custody of his daughter. Another father waited until he was settled in a two-bedroom apartment to get cus- tody of his daughter, and he currently is hoping to be able to move to a larger apartment or house so that he can take his son as well.

Two of the fathers mentioned the mother's overcrowded or dependent living situation as a motivating factor. For instance, John said his home ownership was a pivotal reason for taking custody of his young daughter:

\section{As soon as I bought my home, I wanted my child here with me. Tonya's mother was still living with her mom or her father, like off and on staying with either one of them, and I just wanted my child to have a home. I mean, when I was younger, I stayed with my grandpar- ents, you know; my mother didn't get a home, didn't even move out of [her parents'] house until I was 12 years old. And I just wanted my daughter to have a place that she can call her own.}

The availability of a support system was more prevalent in the fathers' discourse than either employment or housing. For instance, Ronald, whose 2 custodial children are now in their teens, said that along with other considerations, having a support system played an important role in taking custody.

\section{I was going out with a girlfriend at the time who urged me to get them [the children]. She said she would help me as much as she could.... I had a job. I had a house. I had a car. My mom was alive at the time, so I had daycare too. She would watch the kids when I wasn't here, when I was driving taxi or something. She would take them to church every Sunday morning. My sister was always there too to belp out.}

Only one of the fathers, the adoptive father (who is also gay), said his parents were not in favor of his having custody of a child, but even they have become supportive now that the adoption has taken place. Several fathers said family members encouraged them to take custody. Only 3 of the fathers are located far from family and do not have access to family members for childcare, advice, or household assistance. The remaining fathers lived within 5-10 miles of at least some of their family members, most frequently mothers and siblings. Calling upon them for household assistance was uncommon, but the fathers with the youngest children received the most assistance (in the form of childcare) from family members.

Mothers and sisters are the most common kin assisters, although aunts, grandmothers, brothers, and uncles played an occasional role as well. The mothers of the children were regularly involved in about half of the families. Four of the men had had or currently had girlfriends who helped out occasionally, though none resided with a girlfriend at the time of the study. 


\section{Prior Parental Involvement}

In this sample 3 of the fathers indicated that they had handled primary parental responsibilities before single custody. In 2 of those cases, the parents had been married, and in 1 the parents had been cohabiting. In two cases a high level of paternal prior involvement was due to illness on the part of the mother, and in one case it was due to the parents working split shifts in order to save on childcare. Ray's wife worked second shift at a food store.

\section{When I'd get off work, we'd have an overlap time for both of us, maybe of about 45 minutes. And then she'd go off to work. And she didn't get off until 11 p.m., and she had stopped breastfeeding him. So then I was the one who was feeding him. I had to change the diapers and stuff. As I look back on it, I think that was how we bonded.}

However, for the most part, most of the men acknowledged that they had not been the primary caregivers or done the bulk of household chores when they coresided with the mother.

\section{Marital Status and Father's Age at the Birth of the Child}

Although previous studies on single dads appear to indicate that divorced fathers are more likely to take custody than are never-married fathers, this did not appear to be a strong factor among this group of African American fathers. In this sample, 7 fathers had not been married to the mother of their child, and 1 of them was an adoptive father and so had had no relationship to the mother. This may indicate that among Black single fathers, marital status and the parent-child relationship may not be as dependent on one another as they are in the general population of single fathers. However, given the higher divorce-to-never-married ratio among White dads and the higher percentage of never-married status among Black fathers generally, the high number of never-married custodial dads in this sample may merely reflect those differing proportions of divorce and nonmarital births among White and Black men rather than reflecting a higher likelihood that nonmarital Black men will take custody.

Although the fathers' current ages covered a 23-year span ( 20 to 43 years old), they held in common the fact that the vast majority of them were legal adults when they first became parents. Eight of these dads were 20 or older upon the birth of their first child. Only 1 of the fathers was younger than 18 at the time of the birth of his first child. That father did not take custody of the first child, but he did take custody of two of the children born when he was older. Research on teen fathers has indicated that youthful fatherhood is correlated with nonresidence and declining involvement over time (Barnes, 1987; Lerman \& Ooms, 1993).
However, it is difficult to know from this sample whether age at birth itself was a determining factor in child custody or whether it was related in some way to employment and marital status, as older first-time fathers would be more likely to be employed and/or previously married.

\section{Maternal Incompetence and Gender and Number of Children}

Maternal competence (as defined by the father) played somewhat of a role as well and was related to marital status and gender of the custodial children. That is, divorced fathers were slightly more likely than never-married fathers to perceive the mothers as incompetent. Two of the 7 nevermarried fathers perceived the mother to be incompetent, whereas 2 of the 3 divorced fathers described the mother as incompetent. Of the 6 never-married moms, ${ }^{6}$ one was on drugs. A 2 nd mother was described as incompetent by the father because she was neither employed nor seeking employment. However, the court did not define her as incompetent, and the father trusted her to care for the child weekly. A 3rd mother, according to the father, was competent but was residing in an overcrowded family situation. The overcrowding led to an injury to the child, and the state placed the child in foster care. The father went to court to fight for both paternity and custody so that the child would not be in the foster care system. One of the 3 divorced mothers had had several nervous breakdowns, and another, according to the father, was less responsible and just didn't want to parent. The rest of the mothers were generally competent but nevertheless agreed with the fathers that it was beneficial for the child to be with the father.

In the end, however, only 2 of the fathers thought that maternal incompetence played a strong role in their personal decision; these 2 indicated that they probably would not have taken custody if the mother had been competent. However, a number of the men said they were tired of people assuming the only reason they had the children was because the mother didn't want them or couldn't take care of them. Tracy said,

\section{It is really an insult. Because basically they are saying that she don't love her children; she just gave them to [me]. Like I really don't want him; she just gave him to me because she couldn't handle him.... She's not on drugs; she's able to take care of herself; she can take care of the baby. We just wanted him to be with his father.}

The competency of the mother also related to the number of custodial children. As stated earlier, 3 of the 10 fathers had custody of two children, whereas the rest had only 1 . All three of the two-children households had mothers whom the fathers considered incompetent, whereas this was the case for only one of the single-child households.

\footnotetext{
6 I'm not including the mother of the adopted son here, because although she was deemed legally incompetent, her incompetence had nothing to do with the adoptive father's choice to parent.
} 
Girls were slightly more likely to come from incompetent moms, but that may be due to the fact that girls in this sample were more likely than the boys to be part of 2children custody.

A slight majority of custodial children in this sample were girls, though the number of households with girls or boys was equally divided: four households had girls only, four households had boys only, and two households had children of both sexes. This is contrary to the findings of past research, which tended to show that the child's gender plays a role in father custody, with fathers being more likely to have custody of boys.

Most of these dads stated that neither the gender nor age of the child influenced their choice to parent; the fathers of boys thought that they would have taken custody even if their children had been girls. The slight prevalence of girls among the custodial children would appear to uphold their conviction. However, the qualitative data also indicated that fathers of boys were more likely than fathers of girls to identify the desire to be a role model for their boys as one factor in the custody decision. For instance, Tracy, who spent several of his teen years in Ethan Allen (a reform school), said one of his reasons for taking custody of his 9-year-old son was socializing him to be a man.

\section{I always wanted him, but I also knew he needed his mother. So I told her, "You did a good job; we both did." I think we did an outstanding job with him, you know. I think he is going to be ten times better of a human being than I am. But I told her now I think it's time for me to take over and just be the primary parent and you be the secondary. Because he is about to become a man now, you know. I wanted to make sure [he does- n't go through what I went through]... I wanted to be there for puberty and all, because we both know- she hates to admit it, but I tell bim to do something, he does it.}

Only $\mathrm{l}$ father of girls indicated that he took his daughter because he wanted to teach her how to become a woman. Larry, who has custody of his daughter but not his younger son, says he feels that a "boy needs a man." Although he does not have custody of his son, he teaches at the elementary school his son attends, so he sees him daily and drives him to school every morning. In addition, his son stays overnight several times a month. However, Larry also points out one of the reasons he took his daughter: "I just wanted to help teach her how to be respectful, not be like a lot of the girls who become women who have a lot of babies. I want her to go to college, finish school."

Because of the interaction among maternal incompetence, divorced marital status, daughters, and two-child custody, a larger sample size would be needed to tease out the variation in importance of each of these variables.

\section{Family Background}

This sample of fathers is somewhat distinct from earlier findings on single fathers, which showed that the vast majority of fathers had been raised in two-parent families for most, if not all, of their childhood. Only 4 of these fathers came from two-parent families. The majority had spent at least a portion, most at least 11 years, of their childhood in a singleparent family. Four of the 7 single-parent families had experienced a parental divorce; the other 3 had had never-married parents. However, once again this may reflect the higher proportion of single-parent families among African Americans in the last 2 decades, not a higher likelihood that Black men from single-parent homes will take custody.

In one aspect, findings on this sample were similar to Gersick's (1979) findings that single fathers reported being closer to their mothers. Eight of the men reported being closest to their mothers ( 2 said "close to both parents"). They felt their mothers had been loving mothers who served as their role models now or, at worst, felt that their mothers had done the best that they could given the situation. Gersick had attributed her finding to the fact that all her respondents' mothers had been homemakers. However, in this sample, all of the mothers of the fathers had been employed.

Three fathers in this sample said both parents served as role models, although it should be noted that the term role model was sometimes used by respondents to mean what not to do as a parent. The view they held of their fathers differed significantly from the view they held of their mothers. Only 1 of the sample fathers found his own father to be nurturing, and that was qualified by "somewhat." Even those who had grown up in two-parent families or who described their fathers as a "provider" or "there for me" did not report their fathers to be nurturing.

Social learning theory would suggest that boys who grow up without fathers would fail to learn how to parent and would be less likely to take on a parenting role and more likely to repeat the scenario they grew up in and, consequently, remain uninvolved should they have children (Gersick, 1979; Hanson 1985b). However, other qualitative research (Allen \& Doherty, 1998; Daly, 1993; Snarey, 1993) on involvement levels of nonresident fathers has indicated that at least for some men, the desire to reverse the pattern of their own childhood increased the potential for involvement. The qualitative data of this study appear to confirm these latter studies.

Rather than re-create the paternal motif of uninvolved, nonresident fathers that they experienced in their family of orientation, many of these men found their lack of a nurturing father to be a consciously motivating factor in their own parenting experience. More than the anticipated factors mentioned earlier, such as employment, maternal incompetence, gender of child, and so on, the dominant themes of their discourse focused on preventing a repeat of their experience and fulfilling long-held desires for family 
life. For instance, Tracy, a 31-year-old social worker and father of two boys, saw his father three times while he was growing up. Consequently, he said,

So [when my girlfriend became pregnant] I was excited about the baby and her being pregnant. But I wasn't prepared. I mean I didn't know how to be a father. I didn't know anything about that. I mean, my father wasn't around. All I knew is that I was going to be there for him [the baby]. I knew I was going to be there. It was like, you know, I'm not going to do what my father did to me.

Larry, was a second-grade teacher in Milwaukee's public school system and father of a daughter and son. He saw his father once every year or so, and concurred with Tracy:

The day my baby was born, I said, "I gotta find a better life." I had always said that I was not going to be like my daddy. I mean, I had the idea, the dream, as a kid because of some of the things my mother went through. I said, "I don't want my kids to go through any of this shit. I'm going to get married the right way." But, of course, that didn't happen as far as the marriage. But I just said I was not going to abandon my kids... I just wanted - because I never had the opportunity to be with my dad. I just did not want to be like my father.

While this drive to be the kind of father they hadn't had was more prevalent among the men from single-parent families, even some from two-parent families had similar stories. Richard, a gay 32-year-old who had adopted 6-year-old Tyler nearly 3 years earlier, came from a two-parent family. His father was a minister.

When I was growing up, I played Little League baseball for three years. My father never attended one game. I'm sorry. In three years you can get away for one game, at least. You know? And he never did. And I asked him to go out and practice with me so I could hit the ball. He bought me a Johnny Batter-Upper so that I could practice by myself. And, you know, it was like that if he was going to the store - hardware store, or anything like that and I might have wanted to go with him; he said, "No, you stay here." It was always like that.... So I had been wanting to be a good father for years.

One should not conclude from this that the majority of Black men have fathers who are unavailable. Even if this were a random sample, single custodial fathers represent a minority of men and are not typical of the general population of fathers. Indeed, Allen's 1981 study of a group of Black two-parent families found the fathers to be very involved, and McAdoo's 1981 study of 40 Black middle- class families found two thirds of the dads to be nurturing. However, what this does confirm is that for some men, experience with weak or nonexistent fathers acts not as a model to imitate, but rather as a force motivating them to take on more parental responsibilities than is typical of most men. This is not to say that having such experiences will have that effect on the majority of men, but perhaps more than might be expected.

\section{Areas for Future Research}

From this study, I see the need for research on Black single fathers branching in three directions. First, research comparing single-fathers by race might better distinguish the role of family background, marital status, gender of the child, and family support in the decision to parent. However, race-comparative research has its pros and cons. On the negative side is the concern that such research establishes White fathers as the standard by which other groups of fathers should be compared, with the latter inevitably perceived as deficient. On the other hand, the advantage is that such research helps to articulate the role that race continues to play in American society for better or worse. Hence, policies can be better tailored to meet the needs of diverse groups of people, and each group can learn from the other. For instance, the apparently higher use of family support among men in this study is consistent with the higher use of extended family relationships among Blacks as a group and can just as likely be interpreted as an asset that White fathers might want to develop.

Second, research comparing single Black custodial fathers to their noncustodial counterparts could help decipher the impact of socioeconomic status, age, and marital status, as well as uncover factors not considered here. For instance, the fathers in Hamer's (1997) study of nonresidential fathers cited the existence of children by 2 or more mothers (30\% of the fathers in this study were in this situation) or a poor relationship with the mother (in this case, the sample was about evenly split between those who maintained a working relationship with the mother and those who rarely or never saw the mother) as reasons for their weak level of involvement with their children. All of the fathers in this study had friends who were noncustodial fathers. When asked why they thought their friends didn't have custody, a variety of reasons-disagreeable mothers, immaturity, lack of confidence, unwillingness-were offered. A more in-depth study into a matched sample of custodial and noncustodial fathers could be informative for the current plethora of government programs aimed at increasing father involvement among lower income noncustodial single dads.

Finally, although only one of the fathers in the first group of men in this study was an adoptive father, there is potential for more. An increasing number of Black men are adopting children, particularly boys ("More Single Black Men," 1994). 
In some U.S. metropolitan areas, the majority of children in foster care are young African American boys, and consequently a number of adoption agencies are targeting Black men as potential adoptive parents. Adoptive fathers are particularly useful for questions concerning the decision to parent because their lack of prior relationship to the mother and child means their decisions more clearly reflect free choice.

\section{Implications for Social Service Practitioners and Policy}

Because of their income levels, most of the men in this study may be beyond the jurisdiction of government family social services that rely on means testing and hence won't come into contact with such practitioners. Even private social service practitioners, such as counselors and psychologists, may not have much contact because by and large, the vast majority of these fathers were satisfied with their parenting and happy with their decision (Coles, 2002). None of them had sought support through single-father groups. However, social service practitioners may come in contact with people who are related to the father and child-mothers, grandparents, and so forth. In addition, practitioners are in the position to be advocates of policy change. Hence, a number of considerations related to social service practice follow.

First, some of the fathers in this study may be above the requisite poverty levels because they were overemployed in terms of the number of jobs they held and the amount of time they invested in work, a condition that caused concern for a couple of them and led to a heavy reliance on kin for childcare. Several of them were also financially taxed because of the drain on their finances from continuing to pay child support and/or repay the state for past AFDC payments to the children's mothers. In fact, although in the past there had been some concern that welfare presented an incentive for single mothers to have children, the evidence here suggests that for most men there is little financial incentive to have custody. One of the fathers who himself works in a social service agency suggested that noncash services are not designed to help single fathers with children because food pantries, clothing outlets, and shelters tend to be aimed at women with children. Similarly, John, a father of a young daughter, said,

If my mother or her mother would have contested the court or my asking the court for custody, then it would have been much harder. I felt the system doesn't work for fathers as much as mothers. I can't blame the system, because most of the single parents are mothers. But I definitely feel that it doesn't work for fathers. I know a lot of fathers who don't have [custody of] their children, [they] take excellent care of their child, but they are still given a lot of grief from the mother, the courts. It's kind of not fair.
Although the newly reformed welfare system may in theory be designed to meet the needs of families without regard to gender or marital status, practitioners may need to target single fathers directly or through kin to educate them about what services are available to them through TANF and how to access them.

Recently, many family social service agencies have recognized the need to address nonresident, noncustodial fathers as one part of the family matrix (Lerman \& Ooms, 1993). In addition, the use of extended kin (sisters, grandmothers, and aunts, primarily) for childcare (which is a financial subsidy to the parent, but a financial cost to the childcare giver) was illustrated in this study and continues to support the concept of working with whole, extended families, even if they are not residing together.

Moreover, it should be kept in mind that 3 of these fathers were simultaneously custodial fathers to 1 or 2 children and nonresident fathers for other children (this finding is similar to those of Hamer, 1997, and Lerman \& Sorensen, 2000). Therefore, findings from this study suggest that nonresident fathers should be approached as potential custodial parents, with the assumption that most fathers want to repair their own past parenting wounds and do well by their children, even if they currently feel they don't know how or don't have the capacity to do so. Few persons fall easily into a fixed stereotypical niche of good or bad parents.

In conclusion, although Black, single, full-time fathers are a numerical minority, their numbers are apparently increasing. Although they have much in common with other single custodial parents, their ways of doing and talking about parenting deserve more attention in the academic arena, if only because the overconcentration of research on unwed and nonresidential fathers, particularly Black fathers, has given the impression that the concept of "Black men parenting" is an oxymoron. This article, although only beginning to tap this understudied group, indicates that a significant number of single Black men desire and actively seek to parent. They want their voices, even if small in number, to be heard in the din of the "absent father."

\section{References}

Ahmeduzzaman, M., \& Roopnarine, J. (1992). Sociodemographic factors, functioning style, social support, and fathers' involvement with preschoolers in African-American families. Journal of Marriage and the Family, 54, 699-707.

Allen, W. (1981). Mom, dads, and boys: Race and sex differences in the socialization of male children. In L. Gary (Ed.), Black men (pp. 99-114). Beverly Hills, CA: Sage.

Allen, W. D., \& Doherty, W. J. (1998). “Being there:” The perception of fatherhood among a group of African American adolescents. In H. I. McCubbin, E. A. Thompson, A. I. Thompson, \& J. A. Futrell (Eds.), Resiliency in African American families (pp. 207-244). Thousand Oaks, CA: Sage. 
Barker, R. W. (1994). Lone fathers and masculinities. Aldershot, England: Avebury.

Barnes, A. S. (1987). Single parents in Black America: A study in culture and legitimacy. Bristol, IN: Wyndham Hall.

Bartz, K. W., \& Witcher, W. C. (1978, September-October). When father gets custody. Children Today, 2-6, 35.

Bowman, P. (1993). The impact of economic marginality on AfricanAmerican husbands and fathers. In H. McAdoo (Ed.), Family ethnicity (pp. 120-137). Newbury Park, CA: Sage.

Bright, J. A., \& Williams, C. (1996). Child-rearing and education in urban environments: Black fathers' perspectives. Urban Education, 31, 245-264.

Brown, B. V. (2000). The single-father family: Demographic, economic, and public transfer use characteristics. Marriage and Family Review, 29, 203-223.

Chang, P., \& Deinard, A. S. (1982). Single-father caretakers: Demographic characteristics and adjustment processes. American Journal of Orthopsychiatry, 52, 236-242.

Christmon, K. (1990a). Parental responsibility and self-image of African American fathers. Families in Society, 71, 563-567.

Christmon, K. (1990b). Parental responsibility of African-American unwed adolescent fathers. Adolescence, 25, 645-653.

Cochran, D. L. (1997). African American fathers: A decade review of the literature. Families in Society, 78, 340-350.

Coles, R. L. (2002). Single Black custodial fathers: How are they doing? Journal of African American Men, 6(2), 63-82.

Daly, K. (1993). Reshaping fatherhood: Finding the models. Journal of Family Issues, 14, 510-530.

Danziger, S., \& Radin, N. (1990). Absent does not equal uninvolved: Predictors of fathering in teen mother families. Journal of Marriage and the Family, 52, 636-642.

Davis, L. E. (1999). Working with African American males: A guide to practice. Thousand Oaks, CA: Sage.

DeFrain, J., \& Eirick, R. (1981). Coping as divorced parents: A comparative study of fathers and mothers. Family Relations, 30, 265-274.

Diverse living arrangements of children. (1993, July-September). Statistical Bulletin (pp. 2-9). Washington, DC: U.S. Bureau of the Census.

Dowd, N. E. (1997). In defense of single-parent families. New York: New York University Press.

Downey, D. B. (1994). The school performance of children from singlemother and single-father families: Economic or interpersonal deprivation? Journal of Family Issues, 15, 129-147.

Employment opportunities of young men and family formation. (1989, May). American Economic Review, pp. 62-66.

Eggebeen, D. J., Snyder, A. R., \& Manning, W. D. (1996). Children in single-father families in demographic perspective. Journal of Family Issues, 17, 441-465.

Fagan, J. (1998). Correlates of low-income African American and Puerto Rican fathers' involvement with their children. Journal of Black Psychology, 24, 351-368.

Furstenberg, F. F. (1995). Fathering in the inner city: Paternal participation and public policy. In W. Marsiglio (Ed.), Fatherhood: Contemporary theory, research, and social policy (pp. 119-147). Thousand Oaks, CA: Sage.

Furstenberg, F. F., \& Harris, K. (1993). When and why fathers matter: Impacts of father involvement on the children of adolescent mothers. In R. Lerman \& T. Ooms (Eds.), Young unwed fathers: Changing roles and emerging policies (pp. 117-138). Philadelphia: Temple University Press.

Furstenberg, F. F., Morgan, S. P., \& Allison, P. D. (1987). Paternal participation and children's well-being after marital dissolution. American Sociological Review, 52, 695-701.

Gasser, R. D., \& Taylor, C. M. (1976). Role adjustment of single fathers with dependent children. Family Coordinator, 25, 397-401.
George, V., \& Wilding, P. (1972). Motherless families. London: Routledge and Kegan Paul.

Gersick, K. E. (1979). Fathers by choice: Divorced men who receive custody of their children. In G. Levinger \& O. Noles (Eds.), Separation and divorce. New York: Basic Books.

Gladding, S. T., \& Huber, C. H. (1984). The position of the single-parent father. Journal of Employment Counseling, 21, 13-18.

Greene, R. S. (1977). Atypical parenting: Custodial single fathers. Unpublished doctoral dissertation, University of Maryland, College Park.

Greif, G. L. (1982). Dads raising kids. Single Parent, 25, 17-25.

Greif, G. L. (1985). Children and housework in the single father family. Family Relations, 34, 353-357.

Greif, G.L. (1990). The daddy track and the single father. Lexington, MA: Lexington Books.

Greif, G. L., \& DeMaris, A. (1989). Single custodial fathers in contested custody suits. Journal of Psychiatry and Law, 17, 223-238.

Greif, G. L., \& DeMaris, A. (1995). Single fathers with custody: Do they change over time? In W. Marsiglio (Ed.), Fatherhood: Contemporary theory, research, and social policy (pp. 193-210). Thousand Oaks, CA: Sage.

Guttmann, J. (1982). The divorced father: A review of the issues and the research. Journal of Comparative Family Studies, XX, 247-261.

Hamer, J. F. (1997). The fathers of "fatherless" Black children. Families in Society, $78,564-578$

Hanson, S. M. H. (1981). Single custodial fathers and the parent-child relationship. Nursing Research, 30, 202-204.

Hanson, S. M. H. (1985a). Single custodial fathers. In S. M. H. Hanson \& F. W. Bozett (Eds.), Dimensions of fatherhood. Beverly Hills, CA: Sage.

Hanson, S. M. H. (1985b). Single fathers with custody: A synthesis of the literature. In B. Schlesinger (Ed.), The one-parent family in the 1980s: Perspectives and bibliography 1978-1984. Toronto: University of Toronto Press.

Hanson, S. M. H. (1986a). Father-child relationships: Beyond Kramer vs. Kramer. In R. S. Lewis \& M. B. Sussman (Eds.), Men's changing roles in families. New York: Haworth.

Hanson, S. M. H. (1986b). Parent-child relationships in single-father families. In R. Lewis \& B. Salts (Eds.), Men in families. Beverly Hills, CA: Sage.

Hanson, S. M. H. (1988). Divorced fathers with custody. In P. Bronstein \& C. Pape Cowan (Eds.), Fatherhood today: Men's changing role in the family (pp. 166-194). New York: Wiley.

Hawkins, A. J., \& Eggebeen, D. J. (1991). Are fathers fungible? Patterns of co-resident adult men in maritally disrupted families and young children's well-being. Journal of Marriage and the Family, 53, 958-972.

Hipgrave, T. (1982). Lone fatherhood: A problematic status. In L. McKee \& M. O'Brien (Eds.), The father figure. London: Tavistock.

Ihinger-Tallman, M., Pasley, K., \& Buehler, C. (1995). Developing a middlerange theory of father involvement post divorce. In W. Marsiglio (Ed.), Fatherhood: Contemporary theory, research, and social policy (pp. 57-77). Thousand Oaks, CA: Sage.

Johnson, C., \& Sum, A. (1987). Declining earnings of young men: Their relation to poverty, teen pregnancy, and family formation. Washington, DC: Adolescent Pregnancy Prevention Clearinghouse, Children's Defense Fund.

Katz, A. J. (1979). Lone fathers: Perspectives and implications for family policy. Family Coordinator, 28, 521-527.

Keshet, H. F., \& Rosenthal, K. N. (1978, May-June). Single-parent families: A new study. Children Today, 13-17.

Lerman, R. I. (1993). Employment patterns of unwed fathers and public policy. In R. I. Lerman \& T. J. Ooms (Eds.), Young unwed fathers: Changing roles and emerging policies (pp. 316-334). Philadelphia: Temple University Press. 
Lerman, R. I., \& Ooms, T. J. (Eds.). (1993). Young unwed fathers: Changing roles and emerging policies. Philadelphia: Temple University Press.

Lerman, R., \& Sorensen, E. (2000). Father involvement with their nonmarital children: Patterns, determinants, and effects on their earnings. Marriage and Family Review, 29, 137-158.

Madhubuti, H. (1990). Black men: Obsolete, single, dangerous? Chicago: Third World Press.

Marsiglio, W. (1987). Adolescent fathers in the United States: Their initial living arrangements, marital experience and educational outcomes. Family Planning Perspectives, 19, 240-251.

Marsiglio, W. (1991a). Male procreative consciousness and responsibility: A conceptual analysis and research agenda. Journal of Family Issues, 12, 268-290.

Marsiglio, W. (1991b). Paternal engagement activities with minor children. Journal of Marriage and the Family, 53, 973-986.

McAdoo, J. (1981). Involvement of fathers in the socialization of Black children. In H. P. McAdoo (Ed.), Black families (pp. 225-237). Newbury Park, CA: Sage

McAdoo, J. (1988a). Changing perspectives on the role of the Black father. In P. Bronstein \& C. Cowan (Eds.), Fatherhood today: Men's changing role in the family (pp. 79-92). New York: Wiley.

McAdoo, J. (1988b). The roles of Black fathers in the socialization of Black children. In H. P. McAdoo (Ed.), Black families (2nd ed., pp 257-269). Newbury Park, CA: Sage.

McAdoo, J. L. (1993). The roles of African American fathers: An ecological perspective. Families in Society, 74, 28-35.

McAdoo, J. L., \& McAdoo, J. B. (1994). The African-American father's role within the family. In R. Majors \& J. Gordon (Eds.), The American Black male: His present status and his future (pp. 286-297). Chicago: Nelson-Hall.

McKee, L., \& O’Brien, M. (1983). Interviewing men: Taking gender seriously. In E. Gamarinikov, D. Morgan, J. Purvis, \& D. Taylorson (Eds.), The public and the private (pp. 147-161). London: Heinemann.

Mendes, H. A. (1976a). Single fatherhood. Social Work, 21, 308-312.

Mendes, H. A. (1976b). Single fathers. Family Coordinator, 25, 439-444.

Meyer, D. R., \& Garasky, S. (1993). Custodial fathers: Myths, realities, and child support policy. Journal of Marriage and the Family, 55, 73-89.

Miller, D. (1994). Influences on parental involvement of African American adolescent fathers. Child and Adolescent Social Work Journal, 11, 363-379

Mirande, A. (1991). Ethnicity and fatherhood. In F. W. Bozett \& S. M. H. Hanson (Eds.), Fatherhood and families in cultural context (pp. 53-82). New York: Springer.

More single Black men adopting Black children. (1994, October 31) Jet, p. 22.

Morgan, S. P., Lye, D. N., \& Condran, G. A. (1988). Sons, daughters, and the risk of marital disruption. American Journal of Sociology, 94, 110-129.

Mott, F. L. (1990). When is a father really gone? Paternal-child conduct in father-absent homes. Demography, 27, 499-517.

O'Brien, M. (1987). Patterns of kinship and friendship among lone fathers. In Lewis \& O'Brien (Ed.), Reassessing fatherhood: New observations on fathers and the modern family (pp. 225-245). Thousand Oaks, CA: Sage.

Orthner, D., Brown, T., \& Ferguson, D. (1976). Single-parent fatherhood: An emerging family life style. Family Coordinator, 25, 429-437.

Pirog-Good, M. A. (1993). In-kind contributions as child support: The Teen Alternative Parenting Program. In R. Lerman \& T. Ooms (Eds.), Young unwed fathers: Changing roles and emerging policies (pp. 251-266). Philadelphia: Temple University Press.
Risman, B. J. (1986). Can men "mother"? Life as a single father. Family Relations, 35, 95-102.

Rivara, F., Sweeney, P., \& Henderson, B. (1986). Black teenage fathers: What happens when the child is born? Pediatrics, 78, 151-158.

Robinson, B. E. (1988). Teenage fathers. Lexington, MA: Lexington Books.

Robinson, B. E., \& Barrett, R. L. (1986). The developing father: Emerging roles in contemporary society. New York: Guilford.

Rosenthal, K. M., \& Keshet, H. F. (1981). Fathers without partners: A study of fathers and the family after marital separation. Totowa, NJ: Rowman and Littlefield.

Santrock, J. W., \& Warshak, R. A. (1979). Father custody and social development in boys and girls. Journal of Social Issues, 35, 112-125.

Savage, B. D. (1987). Child support and teen parents. Washington, DC: Adolescent Pregnancy Prevention Clearinghouse, Children's Defense Fund.

Seltzer, J. (1991). Relationships between fathers and children who live apart: The father's role after separation. Journal of Marriage and the Family, 53, 79-101.

Single fathers with children increase by $25 \%$. (1998, December 11). The New York Times, p. 22

Smith, R. M., \& Smith, C. W. (1981). Child rearing and single-parent fathers. Family Relations, 30, 411-417.

Snarey. J. (1993). How fathers care for the next generation: A four-decade study. Cambridge, MA: Harvard University Press.

Taylor, R., Chatters, L., Tucker, M. B., \& Lewis, E. (1990). Developments in research on Black families: A decade review. Journal of Marriage and the Family, 52, 993-1014.

Taylor, R. J., Leashore, B. R., \& Toliver, S. (1988). An assessment of the provider role as perceived by Black males. Family Relations, 37, 426-431.

Tedder, S. L., Libbee, K. M., \& Scherman, A. (1981). A community support group for single custodial fathers. Personnel and Guidance Journal, 60, $115-119$.

Turner, J. R. (1984). Divorced fathers who win contested custody of their children: An exploratory study. American Journal of Orthopsychiatry, 54, 498-501.

U. S. Census Bureau. (2002). Income 2000. Retrieved November 24, 2002, from http://www.census.gov/hhes/income/income00/inctab4.html

Wade, J. (1994). African American fathers and sons: Social, historical and psychological considerations. Families in Society, 75, 561-570.

Wattenberg, E. (1993). Paternity actions and young fathers. In R. Lerman \& T. Ooms (Eds.), Young unwed fathers: Changing roles and emerging policies (pp. 213-234). Philadelphia: Temple University Press.

Zill, N. (1988). Behavior, achievement and health problems among children in stepfamilies: Findings from a national survey of child health. In E. M. Hetherington \& J. D. Arasteh (Eds.), Impact of divorce, single parenting, and stepparenting on children (pp. 325-368). Hillsdale, NJ: Erlbaum.

Roberta L. Coles, PhD, is associate professor, Department of Social and Cultural Sciences, Marquette University, 340 LaLumiere Hall, Milwaukee, WI 53233. E-mail: roberta.coles@mu.edu.

Author's note. I thank Janice Staral for her comments. I also thank the fathers who agreed to give their time and share their experiences for this study. 